\title{
The Rift Valley Fever virus protein NSm and putative cellular protein interactions
}

\author{
Cecilia Engdahl', Jonas Näslund ${ }^{1}$, Lena Lindgren ${ }^{1}$, Clas Ahlm and Göran Bucht1,2*
}

\begin{abstract}
Rift Valley Fever is an infectious viral disease and an emerging problem in many countries of Africa and on the Arabian Peninsula. The causative virus is predominantly transmitted by mosquitoes and high mortality and abortion rates characterize outbreaks in animals while symptoms ranging from mild to life-threatening encephalitis and hemorrhagic fever are noticed among infected humans. For a better prevention and treatment of the infection, an increased knowledge of the infectious process of the virus is required.

The focus of this work was to identify protein-protein interactions between the non-structural protein (NSm), encoded by the M-segment of the virus, and host cell proteins. This study was initiated by screening approximately 26 million cDNA clones of a mouse embryonic CDNA library for interactions with the NSm protein using a yeast two-hybrid system.

We have identified nine murine proteins that interact with NSm protein of Rift Valley Fever virus, and the putative protein-protein interactions were confirmed by growth selection procedures and $\beta$-gal activity measurements. Our results suggest that the cleavage and polyadenylation specificity factor subunit 2 (Cpsf2), the peptidyl-prolyl cistrans isomerase (cyclophilin)-like 2 protein (Ppil2), and the synaptosome-associated protein of $25 \mathrm{kDa}$ (SNAP-25) are the most promising targets for the NSm protein of the virus during an infection.
\end{abstract}

Keywords: Rift Valley fever, NSm, Yeast two-hybrid, SNAP-25, Ppil2, Cpsf2

\section{Background}

Rift Valley Fever (RVF) is classified as an emerging infectious disease, first identified in Rift Valley of Kenya in 1930 [1]. RVF was later reported throughout the subSaharan countries and Egypt in 1977-78. By the year 2000 the virus had spread to countries outside the African continent and for the first time was observed in Saudi Arabia and Yemen on the Arabian Peninsula [2,3]. Outbreaks caused by Rift Valley Fever virus (RVFV) results in serious socio-economic and public health impact for endemic communities of the African continent and the Arabian Peninsula.

Rift Valley fever is a reoccurring mosquito-borne viral disease able to cause abortions, fetal malformations and sudden deaths among ruminants; most susceptible are calves, lambs and kids [4-7]. Humans may get infected by the bite of an infected mosquito, by direct contact

\footnotetext{
* Correspondence: goran.bucht@foi.se

${ }^{1}$ Department of Clinical Microbiology, Umeå University, SE-90187, Umeå, Sweden

${ }^{2}$ Swedish Defence Research Agency, SE-90182, Umeå, Sweden
}

with infected animals or through body fluids or tissues thereof $[8,9]$. Symptoms with various severity are observed in humans ranging from influenza-like symptoms to retinitis, encephalitis and/or hemorrhagic fever which may result in a fatal outcome [2,6,10-12]. RVFV is believed to be transmitted by several mosquito species to a wide range of susceptible animals and outbreaks of RVF are linked to rainfall and flooding's that provide for better breeding conditions of the mosquitoes [13].

Several vaccines and vaccine candidates have been developed for livestock and personnel with an occupational risk for the disease, but none are yet approved for public use outside endemic areas [14,15]. Safe vaccines applicable for animals and humans are therefore highly needed to prevent the spread of RVFV. For that purpose, a deeper understanding of the various functions of viral proteins, in combination with a more comprehensive understanding of the infectious process is required.

The RVF virion (Bunyaviridae family, phlebovirus genus) is spherical, $80-120 \mathrm{~nm}$ in diameter and coated by a bi-lipid envelope containing two viral glycoproteins; 
Gn and Gc. The virus has a three-segmented singlestranded RNA genome consisting of small (S), medium (M) and large (L) RNA segments of negative polarity (Additional file 1: Figure S1) $[8,16,17]$. The L-segment encodes the multifunctional RNA-dependent RNA polymerase (RdRp). The S-segment codes for the structural nucleocapsid protein $(\mathrm{N})$, that encapsulates the RNA molecules, and the non-structural protein (NSs) in an ambisense manner. The NSs protein suppresses the host immune response during an infection and is considered as the major virulence factor [18-22]. The $M$ segment encodes two envelope glycoproteins, Gn and Gc, responsible for recognizing host cell receptors, and a nonstructural protein $(\mathrm{NSm})$ with basically unknown function. The $\mathrm{M}$ segment is transcribed into one transcript and the resulting polyprotein is subsequently cleaved into the above protein products. The NSm protein is obtained when translation starts from the second initiation codons (Additional file 1: Figure S1).

The fact that the evolutionary preserved NSm is dispensable for virus replication in cell lines is interesting and indicates an involvement in vivo [23,24]. This suggestion is supported by the finding that RVFV recombinants lacking NSm show reduced virulence in rodents [25]. Other observations suggest that NSm is involved in the suppression of apoptosis [26] probably by activating the p38 MAPK cascade [27].

The main focus of this work was to identify proteinprotein interactions between the NSm protein of RVFV and host cell proteins, with an intention to decipher the functions of this protein during the infectious process. Our results suggest nine putative cellular proteins able to interact with the NSm protein of RVFV; of these the Cpsf2, Ppil2 and SNAP-25 show the strongest interactions when using a yeast two-hybrid system.

\section{Results}

\section{Cloning of NSm gene and screening the mouse-} embryonic cDNA library

The NSm gene of RVFV was amplified by PCR and the resulting product was ligated into the pGBKT7 vector, in fusion with the GAL4 DNA binding domain (BD). Correct clones were verified by DNA sequencing and protein expression in a yeast cell system resulted in a distinct band of the expected size (GAL4 DNA BD and c-Myc epitope tag $<27 \mathrm{kDa}+\mathrm{NSm} 14 \mathrm{kDa}$ ), as identified by SDS-PAGE followed by Western blot analysis (Figure 1).

The initial library screen resulted in 18 open reading frames (ORF's), although the subsequent sequence analysis only identified nine different proteins (Table 1). Interestingly, eight of the 18 clones encoded the ORF of the same protein; the synaptosome-associated protein of $25 \mathrm{kDa}$ (SNAP-25). Furthermore, the ring finger and



$\mathrm{CHY}$ zinc finger domain-containing protein $1 / \mathrm{p} 53-$ Inducible Ring-H2 protein (Rchy1/Pirh2) and the serine/ arginine-rich splicing factor 3 (Srsf3) was represented twice while the remaining six proteins were found as single cDNA clones.

\section{Growth on selective solid media}

To evaluate the interactions between the NSm protein and proteins from the initial screen, the yeast strain $S$. cerevisiae AH109 was pairwise transformed with one of the $18 \mathrm{cDNA}$ clones and plasmid DNA expressing the NSm protein. Accurate interactions are expected to activate transcription of the $A D E 2$ reporter gene and thus allow growth on defined minimal media devoid of 
Table 1 Summary of the cDNA encoded proteins

\begin{tabular}{|c|c|c|c|c|c|}
\hline Gene & Definition & $\begin{array}{c}\text { Size (bp) / } \\
\text { Complete ORF }\end{array}$ & $\begin{array}{l}\text { Number of } \\
\text { clones }\end{array}$ & $\begin{array}{l}\text { Interaction on } \\
\text { solid media* }\end{array}$ & $\begin{array}{c}\beta \text {-gal } \\
\text { activity** }\end{array}$ \\
\hline SNAP-25 & Synaptosome-associated protein of $25 \mathrm{kDa}$ & $411 /$ Yes & 8 & + & $70 \%$ \\
\hline RCHY1 / Pirh2 & $\begin{array}{l}\text { Ring finger and CHY zinc finger domain-containing } \\
\text { protein } 1 / \text { p53-Inducible Ring-H2 protein }\end{array}$ & 786 / Yes & 2 & ++ & $10 \%$ \\
\hline Srsf3 & Serine/arginine-rich splicing factor 3 & 495 / No & 2 & ++ & $0 \%$ \\
\hline Ppil2 & peptidylprolyl isomerase (cyclophilin)-like 2 & $1566 /$ No & 1 & ++ & $150 \%$ \\
\hline Ewsr1 & Ewing sarcoma breakpoint region 1 & 1968 / Yes & 1 & ++ & $10 \%$ \\
\hline St13 & Suppression of tumorigenicity 13 & $1116 /$ Yes & 1 & + & $0 \%$ \\
\hline ND1 & NADH dehydrogenase subunit 1 & 954 / No & 1 & ++ & $50 \%$ \\
\hline Cpsf2 & Cleavage and polyadenylation specificity factor, subunit 2 & $2346 / \mathrm{No}$ & 1 & ++ & $350 \%$ \\
\hline Efcab7 & EF-hand calcium-binding domain-containing protein 7 & $1884 / \mathrm{No}$ & 1 & + & $50 \%$ \\
\hline
\end{tabular}

*Results from growth on selective solid media experiments are presented as; $(+)$, growth at $30^{\circ} \mathrm{C} ;(++)$, growth also at $37^{\circ} \mathrm{C}$.

${ }^{* *}$ Result from the $\beta$-galalactosidase activity measurements are given as Miller units in percentage to the positive control that was set to $100 \%$.

adenine. All 18 ORF's, when co-transformed with the NSm construct, grew well on synthetic defined (SD) solid media (SD-leu/trp/ade) at $30^{\circ} \mathrm{C}$, strengthening our previous observations from the library screen (Figure 2A). Furthermore, yeast cells expressing six of the nine identified proteins were also able to grow at high stringency $\left(37^{\circ} \mathrm{C}\right)$ (Figure $\left.2 \mathrm{~B}\right)$. However, yeast clones expressing SNAP-25, St13 and Efcab7 showed weaker growth at elevated temperature, compared to growth on positive control plates (SD-leu/trp). As negative controls, individual transformation of the plasmids into AH109 did not result in $A D E 2$ gene activation and consequently no growth on selective solid media at the above temperatures (data not shown).

\section{B-galactosidase activity in liquid cultures}

The strength of the interactions between RVFV NSm protein and proteins identified by the library screen was investigated by measuring the $ß$-galactosidase ( $ß$-gal) activity in liquid cultures. Of the 18 clones investigated two proteins; Cpsf2 and Ppil2 induced significantly higher 3 -gal activity than the positive control (Figure 3). The relative induction in Miller units was calculated to 3.5 and 1.5 , respectively. These results are in agreement with the above results from growth on solid media. Furthermore, one of the SNAP-25 clones, together with ND1 and Efcab7, also showed significant interaction with NSm (relative Miller units of 0.7, 0.5 and 0.5 respectively), in contrast to the other examined proteins and negative control samples as shown in Figure 3.

\section{Discussion}

Outbreaks caused by Rift Valley Fever virus are devastating for affected communities and endemic regions of the developing world. In the efforts to develop prevention and efficient medical treatment against RVF, a comprehensive understanding of the infectious process, in combination with a deeper understanding of the molecular functions and relations between viral and host cell proteins, are of outmost importance.

The aim of the study was to identify murine proteins able to interact with the NSm protein of RVFV. For that purpose, an initial yeast mating procedure and library screen of a mouse embryonic cDNA library was conducted that resulted in 18 potential protein interactions. Among the positive clones nine different proteins were identified. The gene products, encoded by the identified clones, were then investigated for their ability to restore growth on selective growth media (SD - leu/trp/ade), as an indicator of reporter gene (ADE2) activation. At $30^{\circ} \mathrm{C}$, all 18 clones grew well when co-expressed with NSm, supporting the results from the library screen. The same set of clones was also analyzed for growth at higher stringency $\left(37^{\circ} \mathrm{C}\right)$; to select for strong protein-protein interactions. At this elevated temperature, six of the 18 clones were able to grow, in addition to the positive control. Consequently, these proteins (Ewsr1, RCHY1/Pirh2, Srsf3, ND1, Cpsf2 and Ppil2) became the most interesting proteins for further analysis.

Unexpectedly, sequence analysis of the 18 cDNA clones concluded that eight of them covered the ORF of the same protein; SNAP-25 (the synaptosome-associated protein of $25 \mathrm{kDa}$ ). SNAP-25 belongs to a family of highly conserved SNARE proteins with a cellular role to mediate vesicle docking, fusion and exocytosis by bringing adjacent cell membranes into close proximity and allowing membrane fusion [28]. SNAP-25 is a cytosolic, membrane-anchored protein that, together with syntaxin and synaptobrevin/VAMP, forms the synaptic SNAREcomplex, responsible for $\mathrm{Ca}^{2+}$-dependent neurotransmission [29]. Expression of SNAP-25 is thus located to neuronal cells [30] mainly located in the brain [31]. Using a rodent model, the accumulation of RVFV to the liver indicates this organ to be a major replication site, 

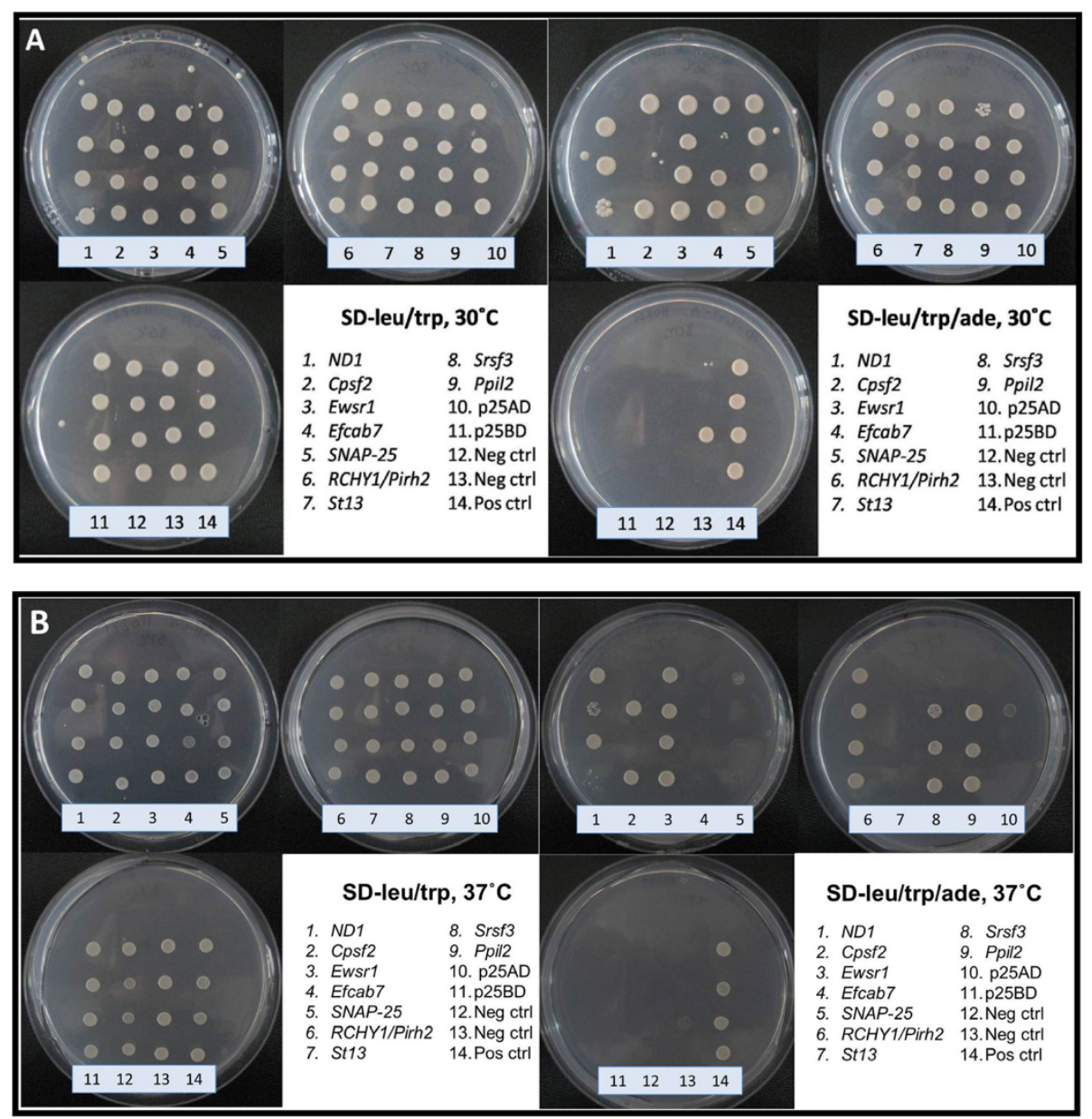

Figure 2 Yeast growth on selective solid media demonstrating NSm interaction with cellular proteins. Figure 2 shows photographs of agar plates demonstrating the growth of individual yeast clones on control plates (SD-leu/trp) and selective solid media (SD-leu/trp/ade) at optimal temperature $(\mathbf{A})$ and elevated temperature (B). The genes encoded by the individual clones are listed within the figure. This figure show one of three individual repeats of this experiment and quadruplets of each yeast construct were tested at each time point.

but increased viral-levels are also found in the brain [32,33]. RVFV invasion to the central nervous system (CNS) may lead to several neurological symptoms, commonly observed at later stages of RVF virus infection $[34,35]$. SNAP-25 has several homologues represented in different tissue types [31]. One example is SNAP-23 which show $72 \%$ similarity to SNAP-25, and has been found to regulate secretion of cytokines from immune cells [36].

The strength of the protein-protein interactions was analyzed using lac $Z$ as the reporter gene and the obtained B-galactosidase activity was used as a semiquantitative indicator for the strength of the interaction, in comparison with the results of the positive control. However, only one of the eight SNAP-25 clones showed high $\beta$-gal levels and this specific clone was chosen for further experiments. Although the Ewsr1, RCHY1/Pirh2 and the Srsf3 proteins also showed positive interactions with the NSm protein by growth experiment on selective solid media, but their $\beta$-gal levels were low and these proteins were therefore excluded from this study.

Ppil2 (the peptidyl-prolyl cis-trans isomerase (cyclophilin)-like 2), also called the cyclophilin 60 (Cyp60) protein, induced significant ß-galactosidase activity. This interesting protein is a member of the cyclophilin family of peptidyl-prolyl isomerases, which is a group of highly conserved ubiquitous proteins [37]. Cyclophilins are involved in catalyzing the cis-trans isomerization reaction of proline, a rate-limiting step of protein folding by acting as chaperones in intracellular protein trafficking. The active site of this protein is the target for the immunosuppressor cyclosporine A (CyA) [38]. CyA is a drug used to suppress rejection of donor organs, and the Cyclophilin/CyA- complex inhibit transcription of several important genes in T-cells and thereby suppresses the immune response [39]. Ppil2 have recently also been shown to regulate cell surface expression of CD147 [38], a widely expressed integral 


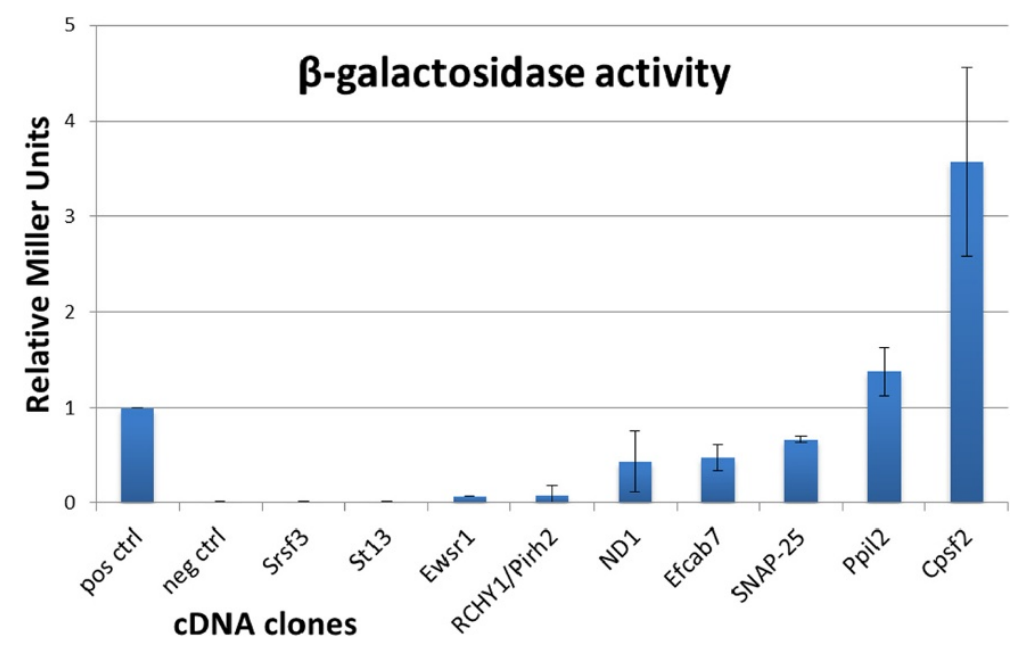

Figure 3 ß-gal activity as an indicator of protein-protein interaction strength. Figure 3 shows a graphical view of the relative strength of the protein-protein interaction based on $\beta$-gal activity measurements between NSm protein and indicated proteins. The strength of the interactions are expressed in Miller units and normalised to the positive control. The presented data and standard deviations are based on four individual experiments and duplicate samples.

plasma membrane glycoprotein. CD147 is responsible for a variety of activities including the role as a receptor for extracellular cyclophilins [40]. The extracellular cyclophilin-CD147 interactions seem to regulate chemotactic responses in many physiological and pathological processes including cell-mediated immunity and inflammation $[38,41]$.

The strongest interaction, as indicated by the $\beta$ galactosidase activity, was obtained when using Cpsf2 (the cleavage and polyadenylation specificity factor subunit 2) as a protein partner for NSm. The Cpsf2 protein is a component of a multi-protein complex that, together with the poly (A) polymerase and several other factors, carry out pre-mRNA 3'-end processing and formation [42] and hence play an important role in nuclear export, translational initiation and transcript stability [43]. Several viral infections are associated with defects in the mechanism of 3'-end processing and polyadenylation of mRNA, for example Influenza A virus and HIV. But, these viruses interact with other subunits of the Cpsf-protein complex [44]. Transcripts of RVFV are not polyadenylated at their 3' ends, indicating that if this interaction plays a role during an infection it may affect the infection indirectly by disturbing the processing of host cell mRNAs.

A noted problem with the yeast two-hybrid screens is the potential risk of getting false positive results. The fact that many of the positive clones obtained from the library screen encode the same protein, and the indicated proteins grow at low and high stringent conditions, further supports our findings. Finally, the clones considered positive showed more than 30 times higher $ß$-gal activity than the negative control.
We believe that the results presented in this study are of high importance since this is the first report to suggest mammalian protein partners for the obscure NSm protein. New knowledge regarding NSm is necessary for a more comprehensive understanding of the role of the NSm protein during the infectious process and for the ongoing search for prevention and treatment of Rift Valley fever. Ongoing experiments include tagging these proteins pair-wise with different epitopes for monoclonal antibodies. Suggested interactions may then be proven by the detection of the corresponding protein partner by pull-down experiments.

Since the continuation of these results may be addressed in a number of different ways, we hope that our results will inspire other groups to address these questions by different approaches.

\section{Conclusion}

It has been difficult to find a role for the RVFV NSm even though the coding sequence of this protein has been preserved over time. The knowledge that NSm is not essential for growth in cultured mammalian cells might suggest that this protein may have roles in pathogenesis and future experiments using animal or mosquito models systems may answer this question. Moreover, we cannot rule out a function for this protein for infection of insect cells.

Our findings suggest several possible protein-protein interactions. The three most interesting proteins from our study are Cpsf2, Ppil2 and SNAP-25. These proteins are all involved in fundamental biological pathways in the eukaryotic cell and could be disturbed if targeted by a viral protein. 


\section{Methods}

Yeast culture and transformation

Growth and transformation of Saccharomyces cerevisiae yeast cells were basically performed according to the Yeast Protocol Handbook (Clontech Laboratories, Inc., Mountain View, CA, USA). Prior to transformation, fresh (not older than 4-5 days) individual colonies of yeast were inoculated in $10 \mathrm{ml}$ liquid YPD medium (10 g yeast extract, $20 \mathrm{~g}$ Difco peptone, $1 \mathrm{~L} \mathrm{H}_{2} \mathrm{O}$, pH: 5.8) supplemented with L-adenine hemisulfate $(20 \mathrm{mg} / \mathrm{L})$, glucose $(2 \%)$ and incubated $\mathrm{o} / \mathrm{n}$ at $30^{\circ} \mathrm{C}$ with shaking (250 rpm). The culture was thereafter diluted with approximately $90 \mathrm{ml}$ fresh medium to an $\mathrm{OD}_{600}$ of $0.2-0.3$ and grown to $\mathrm{OD}_{600}$ 0.5-0.6 before harvested by centrifugation. The obtained samples were washed once by centrifugation and resuspended in $3 \mathrm{ml} 1 \mathrm{xTE} / \mathrm{LiOAc}$ (0.01 M Tris-HCl, 1 M EDTA, pH: 7.5 / $0.1 \mathrm{M} \mathrm{LiOAc,}$ $\mathrm{pH}$ : 7.5). Prior to transformation, $150 \mu \mathrm{l}$ of the yeast cells were added to a mixture of $0.1 \mathrm{mg}$ herring sperm carrier DNA (denatured for $10 \mathrm{~min}$ at $95^{\circ} \mathrm{C}$ ) and $0.1 \mathrm{mg}$ of each DNA plasmid. The samples were mixed thoroughly for one min and $700 \mu \mathrm{l} 1 \mathrm{xTE} / \mathrm{LiOAc} / \mathrm{PEG}$ (40\%) were added. The samples were then incubated for $30 \mathrm{~min}$ at $30^{\circ} \mathrm{C}$ with slow shaking $(75 \mathrm{rpm})$ followed by a $42^{\circ} \mathrm{C}$ heat shock for $20 \mathrm{~min}$. The yeast cells were subsequently collected by centrifugation and the pellets were washed once and resuspended in $150 \mu \mathrm{l}$ of $\mathrm{H}_{2} \mathrm{O}$. The transformation mixture was finally spread on selective solid agar media, SD-leu/trp (to select for both plasmids) and incubated at $30^{\circ} \mathrm{C}$ for $3-4$ days.

\section{Cloning of the NSm gene}

The NSm gene from the RVFV strain ZH548 [45] was amplified by PCR from the second methionine residue of the M-segment, using the forward: 5' - CATG GAGGCCGAATTCATGATTGAAGGAGCTTGGG - 3' and reverse: 5' - GGATCCCCGGGAATTCAGCA AAAACAACAGGTGCC - 3' primers. The primers were designed to extend the 5' and 3' ends of the NSm gene with approximately $15 \mathrm{nt}$ that are homologous to the flanking regions of the EcoRI digested pGBKT7 vector. Prior to transformation, the PCR product was ligated using the In-Fusion ${ }^{\mathrm{TM}}$ PCR Cloning System (Clontech Laboratories, Inc., Mountain View, CA, USA) into the linearized vector, downstream the DNA-BD, the ATG and the c-Myc epitope tag encoded by the vector. Correct constructs were identified in recombinants of $E$. coli by PCR screening and DNA sequencing (Eurofins MWG Operon, Ebersberg, Germany). Plasmid DNA of correct clones were prepared from cultures of E.coli and transformed into the yeast strain AH109 using the above procedures (Table 2). A protein of the correct size was identified by sodium dodecyl sulfate polyacrylamide gel electrophoresis (SDS-PAGE) followed by Western blot analysis. Briefly, the Western blot analysis was performed after transfer of proteins from SDS-PAGE gels to Hybond-N membranes (Amersham Pharmacia Biotech Inc.) and antibodies directed against the $\mathrm{c}-\mathrm{Myc}$ epitope of the tagged fusion protein (NSm + GAL4 DNA-BD) (cMyc monoclonal antibody). Secondary goat-anti-mouse -peroxidase labeled antibodies (Clontech Laboratories Inc.) and the enhanced chemiluminescence (ECL+) kit (Amersham Biosciences) was used to visualize the correct band.

\section{Yeast mating library screen}

Screening procedures of a cDNA library containing approximately 26 million clones (Matchmaker 17 day mEmbryo in Yeast, Clontech Laboratories, Inc.) were done using the yeast mating method according to manufacturer's instructions. Briefly; fresh colonies of two mating strains; Y187 (holding the cDNA library) and AH109, (holding the NSm gene) were incubated $\mathrm{o} / \mathrm{n}$ at $30^{\circ} \mathrm{C}$ in $0.5 \mathrm{ml}$ rich YPD medium. One hundred $\mu \mathrm{l}$ aliquots of the mating culture were thereafter spread on solid SD-leu/trp/ade/his agar plates to select for both plasmids.

\section{Bioinformatics}

The plasmids encoding putative protein-protein partners to NSm, were purified according to manufacturer's instructions using spin Miniprep kit columns (Qiagen

Table 2 Strains and plasmids used in this study

\begin{tabular}{|c|c|c|c|}
\hline Yeast strain & \multicolumn{3}{|c|}{ Genotype } \\
\hline & \multicolumn{3}{|c|}{ MATa, ura3-52, his3-200, ade2-101, trp1-901, leu2-3, } \\
\hline \multirow[t]{2}{*}{ Y187 } & \multicolumn{3}{|c|}{  } \\
\hline & \multicolumn{3}{|c|}{ MATa, ura3-52, his3-200, trp1-901, leu2-3, } \\
\hline \multirow[t]{2}{*}{$\overline{\mathrm{AH} 109}$} & \multicolumn{3}{|c|}{ 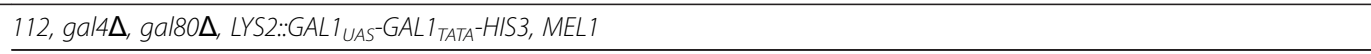 } \\
\hline & \multicolumn{3}{|c|}{ GAL2 $_{\text {UAS }}-$ GAL2 TATA $_{\text {TA }}$-ADE2, URA3::MEL $1_{\text {UAS }}-M E L 1_{\text {TATA }}-$ IaCZ } \\
\hline Plasmid & Size (kb) & Selectable marker on SD-media & Additional information \\
\hline pGADT7 & 8.0 & -Leu & $\mathrm{GAL4}_{(768-881)} \mathrm{AD}, \mathrm{LEU} 2, \mathrm{amp}^{r}, \mathrm{HA}$ epitope tag \\
\hline pGBKT7 & 7.3 & $-\operatorname{Trp}$ & GAL4 $_{(1-147)}$ DNA-BD, TRP1, kan', c-Myc epitope tag \\
\hline
\end{tabular}


Inc., Hilden, Germany) and the inserts were sequenced by Eurofins MWG Operon, Ebersberg, Germany with T7 and $\mathrm{AD}$ sequencing primers, as suggested by the pGADT7AD information data sheet (Clontech Laboratories, Inc., Mountain View, CA, USA). The obtained sequences were finally analysed by using SeqMan Pro; Version 8.1.5(3), 414 (Lasergene, DNASTAR ${ }^{\mathrm{ru}}$ ) and the resulting gene sequences were analysed against the NCBI GenBank database to determine the identity of the encoded gene products.

\section{Plate selection assay}

The protein-protein interactions between the NSm protein and clones of the library were investigated by growth on SD media through a selection procedure using the principle of yeast two-hybrid system. In summary, the S. cerevisiae reporter strain AH109 was cotransformed with the plasmid pGADT7 expressing the GAL4 activating domain (AD), fused to proteins of the initial library screen, and the GAL4 DNA-BD plasmid pGBKT7 fused to the RVF NSm gene (Table 2). After four days of growth on SD-leu/trp plates, four fresh colonies were picked and resuspended in $50 \mu \mathrm{l}$ of sterile water. Aliquots of $5 \mu \mathrm{l}$ were thereafter spotted on two sets of replica plates; each set containing one SD-leu/trp (control plate) and one SD-leu/trp/ade (selective media) and incubated for another four days. The first set of plates was incubated at $30^{\circ} \mathrm{C}$ while the second set was kept at $37^{\circ} \mathrm{C}$. Growth on the selective media (SD-leu/ trp/ade) indicates that protein-protein interaction has occurred through induced transcription of the $A D E 2$ reporter gene. The constructs pGADT7 carrying F. tularensis IglA and pGBKT7 carrying $F$. tularensis IglB (kindly provided by Jeanette Bröms) was used as positive control [46]. S. cerevisiae strain AH109 co-transformed with either pGADT7:IglA and pGBKT7:NSm or pGADT7:NSm and pGBKT7:IglB were used as negative controls.

\section{ß-galactosidase assay}

The strength of the protein interactions towards the NSm protein were also investigated by measuring the $B$ galactosidase ( $($-gal) activity in liquid cultures. Briefly, the S. cerevisiae reporter strain Y187 was co-transformed, as described above for AH109 and yeast cells, and grown in $5 \mathrm{ml}$ selective $\mathrm{SD}$-leu/trp medium at $30^{\circ} \mathrm{C}$ (Table 2). Overnight cultures were diluted in $6 \mathrm{ml}$ rich YPDmedium to $\mathrm{OD}_{600}$ of $0.2-0.3$ and aliquots of $1.5 \mathrm{ml}$ of each culture were harvested at an $\mathrm{OD}_{600}$ of $0.5-0.8$, by centrifugation, washed once and resuspended in $300 \mu \mathrm{l}$ Z-buffer (16.1 $\mathrm{g} \mathrm{Na}_{2} \mathrm{HPO}_{4} * 7 \mathrm{H}_{2} \mathrm{O}, 5.5 \mathrm{~g} \mathrm{NaH}_{2} \mathrm{PO}_{4}{ }^{*} \mathrm{H}_{2} \mathrm{O}$, $\left.0.75 \mathrm{~g} \mathrm{KCl}, 0.246 \mathrm{~g} \mathrm{MgSO}_{4} * 7 \mathrm{H}_{2} \mathrm{O}, 1 \mathrm{~L} \mathrm{H}_{2} \mathrm{O}, \mathrm{pH}: 7.0\right)$. Samples of $100 \mu \mathrm{l}$ were lysed by three cycles of freezethawing in liquid nitrogen and $37^{\circ} \mathrm{C}$ water bath, before the enzyme activity was analysed using Z-buffer containing $0.27 \% ß$-mercaptoethanol and $4 \mathrm{mg} / \mathrm{ml}$ of ONPG (ortho-nitrophenol- $\beta$-D-galactopyranoside) as substrate. The reaction mixture was incubated at $30^{\circ} \mathrm{C}$ before stopped at different time points by the addition of $400 \mu \mathrm{l}$ $\mathrm{Na}_{2} \mathrm{CO}_{3}(1 \mathrm{M})$. Cell debris was removed by centrifugation for $10 \mathrm{~min}$ at $14000 \mathrm{rpm}$ and $\mathrm{OD}_{420}$-values were recorded. The expressed enzyme activity was calculated in Miller units as described earlier [47] and normalised to the positive control (100\%).

\section{Additional file}

\begin{abstract}
Additional file 1: Figure S1. A schematic figure of the threesegmented RVFV genome. Additional file 1: Figure S1 illustrates the three-segmented RVFV genome, the size of the three RNA segments and the encoded proteins. The upper part of the figure shows the $S$ segment and the two genes encoding the N and NSs protein with the intergenomic region separating the two coding sequences. The middle part of this figure demonstrates the $L$ segment and the multifunctional RNA dependent RNA polymerase (RdRp) protein encoded in an antisense manner. The cartoon at the bottom of the figure shows the M segment and the polyprotein precursor that is subsequently cleaved into the NSm, $\mathrm{Gn}$ and Gc proteins. The five potential in frame translation initiation codons are shown below in a magnified picture of the NSm encoding region. The $F$ and the $R$ primers used to amplify the NSm gene, from the proposed second AUG codon, are also shown.
\end{abstract}

\section{Competing interests}

The authors declare that they have no competing interests.

\section{Authors' contributions}

CE and JN performed the practical work, did the analyses and contributed to writing of the manuscript. LL performed the screening of the library and cloning of the NSm gene. CA participated in coordination and contributed to the writing and proof reading. GB participated in the study design, coordination and drafting of the manuscript. All authors read and approved the final manuscript.

\section{Acknowledgements}

We thank Jeanette Bröms for providing us with yeast strains and controls, which were essential for this study. This project was supported by grants from the Medical Faculty of Umeå University, the County Council of Västerbotten and the County Councils of Northern Sweden.

Received: 27 January 2012 Accepted: 17 July 2012

Published: 28 July 2012

\section{References}

1. Daubney R, Garnham P: Enzootic hepatitis of Rift Valley fever: an undescribed virus disease of sheep, cattle and man from East Africa. J Pathol Bacteriol 1931, 34:8922-8926.

2. Meegan JM: The Rift Valley fever epizootic in Egypt 1977-78. 1. Description of the epizzotic and virological studies. Trans $R$ Soc Trop Med Hyg 1979, 73:618-623.

3. Shoemaker T, Boulianne C, Vincent MJ, Pezzanite L, Al-Qahtani MM, AlMazrou Y, Khan AS, Rollin PE, Swanepoel R, Ksiazek TG, Nichol ST: Genetic analysis of viruses associated with emergence of Rift Valley fever in Saudi Arabia and Yemen, 2000-01. Emerg Infect Dis 2002, 8:1415-1420.

4. Coetzer JA: The pathology of Rift Valley fever. I. Lesions occurring in natural cases in new-born lambs. Onderstepoort J Vet Res 1977, 44:205-211.

5. Coetzer JA: The pathology of Rift Valley fever. II. Lesions occurring in field cases in adult cattle, calves and aborted foetuses. Onderstepoort J Vet Res 1982, 49:11-17 
6. Jost CC, Nzietchueng S, Kihu S, Bett B, Njogu G, Swai ES, Mariner JC: Epidemiological assessment of the Rift Valley fever outbreak in Kenya and Tanzania in 2006 and 2007. AmJTrop Med Hyg 2010, 83:65-72.

7. Munyua P, Murithi RM, Wainwright S, Githinji J, Hightower A, Mutonga D, Macharia J, Ithondeka PM, Musaa J, Breiman RF, et al: Rift Valley fever outbreak in livestock in Kenya, 2006-2007. AmJTrop Med Hyg 2010, 83:58-64.

8. Flick R, Bouloy M: Rift Valley fever virus. Curr Mol Med 2005, 5:827-834.

9. Gerdes GH: Rift Valley fever. Rev Sci Tech 2004, 23:613-623.

10. Pepin M, Bouloy M, Bird BH, Kemp A, Paweska J: Rift Valley fever virus (Bunyaviridae: Phlebovirus): an update on pathogenesis, molecular epidemiology, vectors, diagnostics and prevention. Vet Res 2010, 41:61

11. Madani TA, Al-Mazrou YY, Al-Jeffri MH, Mishkhas AA, Al-Rabeah AM, Turkistani AM, Al-Sayed MO, Abodahish AA, Khan AS, Ksiazek TG, Shobokshi O: Rift Valley fever epidemic in Saudi Arabia: epidemiological, clinical, and laboratory characteristics. Clin Infect Dis 2003, 37:1084-1092.

12. Mohamed M, Mosha F, Mghamba J, Zaki SR, Shieh WJ, Paweska J, Omulo S, Gikundi S, Mmbuji P, Bloland P, et al: Epidemiologic and clinical aspects of a Rift Valley fever outbreak in humans in Tanzania, 2007. AmJTrop Med Hyg 2010, 83:22-27.

13. Chevalier V, Pépin M, Plée L, Lancelot R: Rift Valley fever-a threat for Europe? Eur Surveill 2010, 15:19506.

14. Bouloy M, Flick R: Reverse genetics technology for Rift Valley fever virus: current and future applications for the development of therapeutics and vaccines. Antivir Res 2009, 84:101-118.

15. Ikegami T, Makino S: Rift valley fever vaccines. Vaccine 2009, 27(Suppl 4): D69-D72.

16. Elliott RM: The Bunyaviridae. New York: Plenum Press; 1996.

17. Swanepoel R, Burt FJ: Principles and Practice of Clinical Virology. 6th edition. John Wiley \& Sons Ltd; 2009.

18. Billecoca A, Spiegel M, Vialat P, Kohl A, Weber F, Bouloy M, Haller O: NSs protein of Rift Valley fever virus blocks interferon production by inhibiting host gene transcription. J Virol 2004, 78:9798-9806.

19. Bouloy M, Janzen C, Vialat P, Khun H, Pavlovic J, Huerre M, Haller O: Genetic evidence for an interferon-antagonistic function of rift valley fever virus nonstructural protein NSs. J Virol 2001, 75:1371-1377.

20. Ikegami T, Narayanan K, Won S, Kamitani W, Peters CJ, Makino S: Dual functions of Rift Valley fever virus NSs protein: inhibition of host mRNA transcription and post-transcriptional downregulation of protein kinase PKR. Ann N Y Acad Sci 2009, 1171(Suppl 1):E75-E85.

21. Le May N, Dubaele S, Proietti De Santis L, Billecocq A, Bouloy M, Egly JM: TFIIH transcription factor, a target for the Rift Valley hemorrhagic fever virus. Cell 2004, 116:541-550.

22. Mansuroglu Z, Josse T, Gilleron J, Billecocq A, Leger P, Bouloy M, Bonnefoy E: Nonstructural NSs protein of rift valley fever virus interacts with pericentromeric DNA sequences of the host cell, inducing chromosome cohesion and segregation defects. J Virol 2010, 84:928-939.

23. Won S, Ikegami T, Peters CJ, Makino S: NSm and 78-kilodalton proteins of Rift Valley fever virus are nonessential for viral replication in cell culture. J Virol 2006, 80:8274-8278.

24. Gerrard SR, Bird BH, Albariño CG, Nichol ST: The NSm proteins of Rift Valley fever virus are dispensable for maturation, replication and infection. Virology 2007, 359:459-465.

25. Bird BH, Albariño CG, Nichol ST: Rift Valley fever virus lacking NSm proteins retains high virulence in vivo and may provide a model of human delayed onset neurologic disease. Virology 2007, 362:10-15.

26. Won S, Ikegami T, Peters CJ, Makino S: NSm protein of Rift Valley fever virus suppresses virus-induced apoptosis. J Virol 2007, 81:13335-13345.

27. Narayanan A, Popova T, Turell M, Kidd J, Chertow J, Popov SG, Bailey C, Kashanchi F, Kehn-Hall K: Alteration in superoxide dismutase 1 causes oxidative stress and p38 MAPK activation following RVFV infection. PLOS One 2011, 6:e20354.

28. Fasshauer D, Antonin W, Subramaniam V, Jahn R: SNARE assembly and disassembly exhibit a pronounced hysteresis. Nat Struct Biol 2002, 9:144-151.

29. Hanson PI, Heuser JE, Jahn R: Neurotransmitter release - four years of SNARE complexes. Curr Opin Neurobiol 1997, 7:310-315.

30. Oyler GA, Higgins GA, Hart RA, Battenberg E, Billingsley M, Bloom FE, Wilson $M C$ : The identification of a novel synaptosomal-associated protein, SNAP-25, differentially expressed by neuronal subpopulations. J Cell Biol 1989, 109:3039-3052.
31. Ravichandran V, Chawla A, Roche PA: Identification of a novel syntaxinand synaptobrevin/VAMP-binding protein, SNAP-23, expressed in nonneuronal tissues. J Biol Chem 1996, 271:13300-13303.

32. Näslund J, Lagerqvist N, Lundkvist A, Evander M, Ahlm C, Bucht G: Kinetics of Rift Valley Fever Virus in experimentally infected mice using quantitative real-time RT-PCR. J Virol Methods 2008, 151:277-282.

33. Smith DR, Steele KE, Shamblin J, Honko A, Johnson J, Reed C, Kennedy M, Chapman JL, Hensley LE: The pathogenesis of Rift Valley fever virus in the mouse model. Virology 2010, 407:256-267.

34. Ikegami T, Makino S: The Pathogenesis of Rift Valley Fever. Viruses 2011, 3:493-519.

35. Alrajhi AA, Al-Semari A, Al-Watban J: Rift Valley fever encephalitis. Emerg Infect Dis 2004, 10:554-555.

36. Stanley AC, Lacy P: Pathways for cytokine secretion. Physiology (Bethesda) 2010, 25:218-229.

37. Wang BB, Hayenga KJ, Payan DG, Fisher JM: Identification of a nuclearspecific cyclophilin which interacts with the proteinase inhibitor eglin c. Biochem J 1996, 314(Pt 1):313-319.

38. Pushkarsky T, Yurchenko V, Vanpouille C, Brichacek B, Vaisman I, Hatakeyama S, Nakayama Kl, Sherry B, Bukrinsky MI: Cell surface expression of CD147/EMMPRIN is regulated by cyclophilin 60. J Biol Chem 2005, 280:27866-27871.

39. Barik S: Immunophilins: for the love of proteins. Cell Mol Life Sci 2006, 63:2889-2900

40. Yurchenko V, Constant S, Eisenmesser E, Bukrinsky M: Cyclophilin-CD147 interactions: a new target for anti-inflammatory therapeutics. Clin Exp Immunol 2010, 160:305-317.

41. Bukrinsky Ml: Cyclophilins: unexpected messengers in intercellular communications. Trends Immunol 2002, 23:323-325.

42. Jenny A, Hauri HP, Keller W: Characterization of cleavage and polyadenylation specificity factor and cloning of its 100-kilodalton subunit. Mol Cell Biol 1994, 14:8183-8190.

43. Edmonds M: A history of poly A sequences: from formation to factors to function. Prog Nucleic Acid Res Mol Biol 2002, 71:285-389.

44. Danckwardt S, Hentze MW, Kulozik AE: 3 ' end mRNA processing: molecular mechanisms and implications for health and disease. EMBO J 2008, 27:482-498.

45. Sall AA, Zanotto PM, Sene OK, Zeller HG, Digoutte JP, Thiongane Y, Bouloy M: Genetic reassortment of Rift Valley fever virus in nature. J Virol 1999, 73:8196-8200

46. Bröms JE, Lavander $M$, Sjöstedt A: A conserved alpha-helix essential for a type VI secretion-like system of Francisella tularensis. J Bacterio/ 2009, 191:2431-2446.

47. Miller JH: Experiments in Molecular Genetics. New York: Cold Spring Harbor Laboratory; 1972

\section{doi:10.1186/1743-422X-9-139}

Cite this article as: Engdahl et al:: The Rift Valley Fever virus protein NSm and putative cellular protein interactions. Virology Journal 2012 9:139.

\section{Submit your next manuscript to BioMed Central and take full advantage of:}

- Convenient online submission

- Thorough peer review

- No space constraints or color figure charges

- Immediate publication on acceptance

- Inclusion in PubMed, CAS, Scopus and Google Scholar

- Research which is freely available for redistribution 